Instrumental Achievements

\title{
Improved o-Sulfophenylfluorone-Titanium(IV) Complex Method for Total Urinary Protein Assay
}

\author{
Yoshikazu FujIta, Itsuo Mori and Takako Matsuo \\ Osaka University of Pharmaceutical Sciences, Nasahara, Takatsuki, Osaka 569-11, Japan
}

Keywords Total urinary protein assay, spectrophotometry, $o$-sulfophenylfluorone-titanium(IV) complex, albumin, $\gamma$-globulin

We have been working toward the determination of proteins by using dye-metal ion complex systems ${ }^{1-9}$, such as Pyrogallol Red-molybdenum(VI) complex (denoted by PR method). As these methods are characterized by better precision, sensitivity and practicability, interest has arisen concerning the use of dye-metal ion complex methods for determining urinary protein. Among the proposed methods, $o$-sulfophenylfluorone-titanium(IV) [denoted by SPF-Ti(IV)] complex method ${ }^{6}$ is sensitive and precise; it experiences little interference by coexisting substances and shows good contrast with a blank solution, in comparison with other methods. However, a major problem with the assay is the variation in response to different proteins, especially the albumin-to$\gamma$-globulin variation. Incidentally, during the course of our investigations concerning determination of protein, we have suggested that the sensitivity and selectivity of the proposed methods are dependent on dye, metal ion and/or surfactant. This report discusses how to minimize albumin-to- $\gamma$-globulin variation and at the same time how to increase sensitivity of the assay, by re-examining analytical conditions of the SPF-Ti(IV) method. ${ }^{6}$

\section{Experimental}

\section{Reagents and solutions}

Standard solutions $(100 \mu \mathrm{g} / \mathrm{ml})$ of human serum albumin (HSA) and human $\gamma$-globulin $(\gamma-G)$ were prepared by dissolving HSA (Sigma Chemical Co., essential fatty acid-free, Fraction V) in water and $\gamma-G$ (Sigma Chemical Co., purified from Cohn Fractions II, III) in $0.2 \%$ sodium chloride solution, respectively. A Ti(IV) standard solution ( $1.0 \times 10^{-3} \mathrm{M}, 1 \mathrm{M}=1 \mathrm{~mol} \mathrm{dm}^{-3}$ ) was prepared from a stock solution (Wako Pure Chem., $1000 \mu \mathrm{g} / \mathrm{ml}$ ) by dilution with $0.1 \mathrm{M}$ hydrochloric acid. A solution $\left(1.0 \times 10^{-3} \mathrm{M}\right)$ of $\mathrm{SPF}$, which had been synthesized according to the method described in the literature ${ }^{10}$, was prepared in $1.0 \times 10^{-3} \mathrm{M}$ methanol solution containing $1 \mathrm{~cm}^{3}$ of a $1 \mathrm{M}$ sodium hydroxide solution. A surfactant solution was obtained by dissolving $2.5 \mathrm{~g}$ of poly ( $N$-vinylpyrrolidone) (PVP, K-90) and $1.25 \mathrm{~g}$ polyethylene glycol $p$-nonylphenylether (Triton N-101) in water to $100 \mathrm{ml}$. A $0.05 \mathrm{M}$ citric acidsodium citrate buffer solution was used for the $\mathrm{pH}$ adjustments. All other reagents and materials were of analytical grade, and were used without further purification.

\section{Apparatus}

A Shimadzu Model UV-160 recording spectrophotometer with $1.0-\mathrm{cm}$ silica cells was used for conventional measurements. The $\mathrm{pH}$ measurements were made with a Horiba F-11 pH meter combining with a calomel electrode.

\section{Standard procedure for total urinary protein assay}

The following components were mixed in a $10-\mathrm{cm}^{3}$ volumetric flask: $0.5 \mathrm{~cm}^{3}$ of a $1.0 \times 10^{-3} \mathrm{M} \mathrm{Ti}(\mathrm{IV})$ solution, $2.0 \mathrm{~cm}^{3}$ of the surfactant solution, $3.0 \mathrm{~cm}^{3}$ of the buffer solution (pH 2.2), $0.5 \mathrm{~cm}^{3}$ of a $1.0 \times 10^{-3} \mathrm{M}$ SPF solution and a solution containing $5-200 \mu \mathrm{g}$ of protein. The mixture was diluted to $10 \mathrm{~cm}^{3}$ with water, transferred into a test tube, mixed well and kept at $70^{\circ} \mathrm{C}$ for $30 \mathrm{~min}$. After the solution had been cooled for $5 \mathrm{~min}$ in water, the absorbance of the resultant solution was measured at $590 \mathrm{~nm}$ against a reagent blank prepared in the same way.

\section{Results and Discussion}

\section{Effects of metal ions and optimal $\mathrm{pH}$}

The effectiveness of different metal ions at various pH's was compared by measuring the absorbance of a SPF-metal ion-HSA solution against an SPF-metal ion solution. We re-confirmed that Ti(IV) was superior to the other metal ions tested with regard to sensitivity, width of optimal $\mathrm{pH}$ range and low absorbance of a reagent blank: the metal ions used were Ti(IV), molyb$\operatorname{denum}(\mathrm{VI})$, tungsten(VI), tantalum(V), vanadium(V), tin(IV), bismuth(III), antimony(III) and indium(III). 

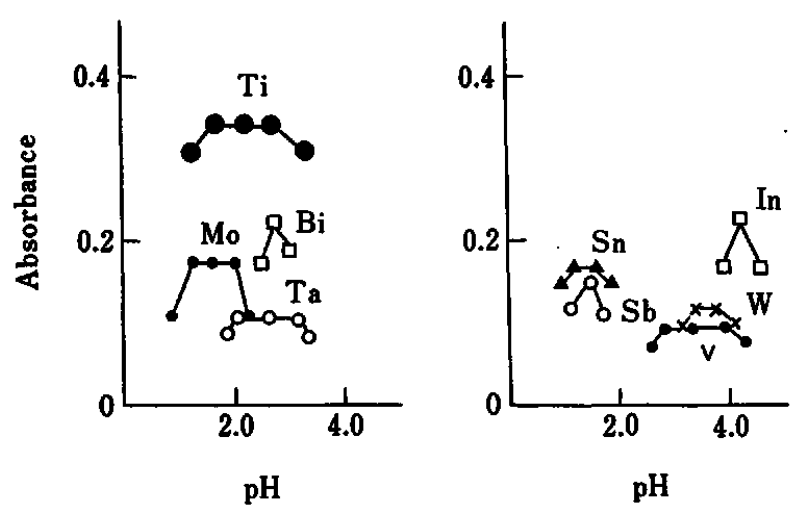

Fig. 1 Effect of metal ions at various pH's. [HSA] $=50 \mu \mathrm{g}$; $[\mathrm{SPF}]=5.0 \times 10^{-5} \mathrm{M}$; [metal ion] $=5.0 \times 10^{-5} \mathrm{M}$; reference, each SPF-metal ion solution.

Table 1 Effect of surfactants on color intensity of HSA and $\gamma-\mathrm{G}$

\begin{tabular}{llc}
\hline \multirow{2}{*}{ Surfactant } & \multicolumn{2}{c}{ Absorbance at 590 nm } \\
\cline { 2 - 3 } & HSA & $\gamma-\mathrm{G}(\%)^{\mathrm{a}}$ \\
\hline PVP+Triton N-101 & 0.330 & $0.324(98.2)$ \\
PVP+Triton X-405 & 0.307 & $0.209(68.1)$ \\
PVP+PVA & 0.284 & $0.201(70.8)$ \\
Triton N-101 & 0.308 & $0.196(63.6)$ \\
Triton X-405 & 0.313 & $0.193(61.6)$ \\
PVP (K-90) & 0.321 & $0.232(72.3)$ \\
PVA ( $n$ : 500) & 0.314 & $0.205(65.3)$ \\
Tween 80 & 0.274 & $0.188(68.6)$ \\
Brij 58 & 0.299 & $0.192(64.2)$ \\
\hline
\end{tabular}

HSA and $\gamma$-G taken, $50 \mu \mathrm{g}$; SPF, $5.0 \times 10^{-5} \mathrm{M}$; Ti(IV), 5.0X $10^{-5} \mathrm{M}$; surfactant, respective suitable concentrations; $\mathrm{pH}$, 2.2; reference, SPF-Ti(IV) solution.

a. Percent with respect to HSA.

b. Polyvinyl alcohol.

The results are shown in Fig. 1.

\section{Choice of surfactant}

The effect of different surfactants was examined by measuring the absorbances of an SPF-Ti(IV)-HSA and an SPF-Ti(IV)- $\gamma$-G solutions against an SPF-Ti(IV) solution. Among the surfactants tested, the use of a combination of PVP and Triton N-101 was superior to the others as regards sensitivity to HSA and $\gamma-G$ and equality of color development of both. It seems likely that the advantage of the use of a combination of PVP and Triton N-101 correlates with the interaction between the surfacants and SPF-Ti(IV) complex or proteins or both. But further investigation is necessary to confirm this. The results are summarized in Table 1.

\section{Optimization of conditions}

As shown in Fig. 1, the best $\mathrm{pH}$ range was from 1.7 to 2.7. Further experiments were carried out at $\mathrm{pH} 2.2$

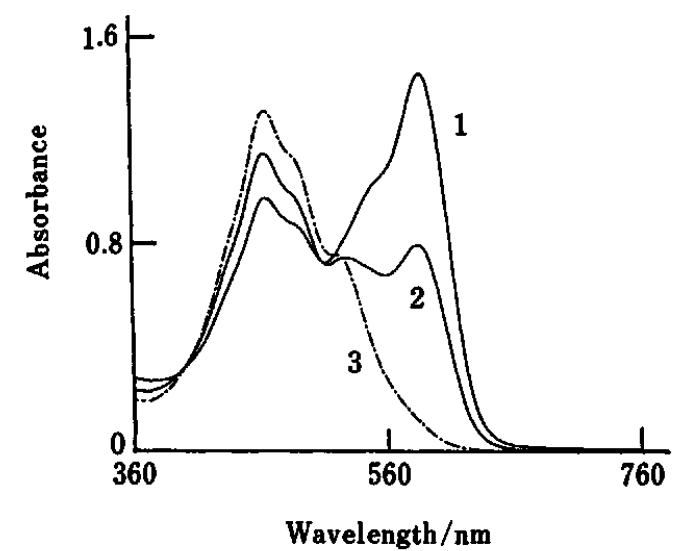

Fig. 2 Absorption spectra of SPF-Ti(IV)-HSA $(=\gamma-G)$ and SPF-Ti(IV) solutions. [HSA or $\gamma-G]=200 \mu$ g (curve 1), $100 \mu \mathrm{g}$ (curve 2); curve 1 and 2, SPF-Ti(IV)-HSA $(=\gamma-\mathrm{G})$ solution; curve 3 , SPF-Ti(IV) solution; reference, water.

using $3.0 \mathrm{~cm}^{3}$ of $0.05 \mathrm{M}$ citric acid-sodium citrate buffer solution. The effects of the PVP and Triton N-101 concentrations were examined. The use of an approximate $0.75 \%$ PVP and $0.375 \%$ Triton X-101 in the final concentration was the most suitable in terms of sensitivity and stability of coloration.

The effect of the amount of SPF was examined, maintaining a fixed final concentration of Ti(IV) (5.0X $\left.10^{-5} \mathrm{M}\right)$. The use of $5.0 \times 10^{-5} \mathrm{M}$ SPF in the final concentration was the best, namely the ratio of SPF to Ti(IV) was $1: 1$.

The color formation in this reaction system did not occur instantaneously at room temperature, more than $180 \mathrm{~min}$ being required for completion of the color reaction. The effects of incubation temperature and time were examined at $40,50,60,70$ and $80^{\circ} \mathrm{C}$. Experiments proved that maximum and constant absorbance was obtained on heating at $70^{\circ} \mathrm{C}$ for $30 \mathrm{~min}$, following by cooling to room temperature. The absorbance remained constant for at least $3 \mathrm{~h}$ after the solution had been cooled to room temperature.

The same absorbance was obtained even when the order in the addition of the reagents was varied.

Figure 2 shows the absorption spectra of SPF-Ti(IV)HSA ( $=$ SPF-Ti(IV)- $\gamma-G)$ and SPF-Ti(IV) solutions under the standard procedure. The maximum absorption of the sample solution by the improved method showed a smaller bathochromic shift than that produced by the previous method. ${ }^{6}$

\section{Calibration curve}

Beer's law was obeyed at $590 \mathrm{~nm}$, in the range 5$200 \mu \mathrm{g}$ of HSA $(=\gamma-G)$ in the final volume of $10 \mathrm{~cm}^{3}$. The sensitivity of the present modified SPF-Ti(IV) method is about 3 times and 1.3 times greater than the PR method ${ }^{1}$ and the previous SPF-Ti(IV) method $^{6}$, respectively. The difference of the reactivity of HSA and $\gamma-G$ was small by comparison to values for other 
Table 2 Effect of foreign substances on assay of HSA

\begin{tabular}{lcc}
\hline \multicolumn{1}{c}{ Substance } & Added $/ \mu \mathrm{g}$ & Recovery, $\%$ \\
\hline $\mathrm{Mg}^{2+}$ & $2.4 \times 10^{3}$ & 100.0 \\
$\mathrm{Ca}^{2+}$ & $4.0 \times 10^{3}$ & 100.0 \\
$\mathrm{Fe}^{3+}$ & $2.8 \times 10^{2}$ & 105.2 \\
$\mathrm{Cu}^{2+}$ & $6.5 \times 10^{2}$ & 100.0 \\
$\mathrm{NaCl}^{2+}$ & $5.8 \times 10^{3}$ & 100.0 \\
$\mathrm{KH}_{2} \mathrm{PO}_{4}$ & $2.7 \times 10^{3}$ & 96.3 \\
$\mathrm{NaF}$ & $8.4 \times 10^{3}$ & 98.1 \\
Urea & $6.0 \times 10^{3}$ & 100.0 \\
Glycine & $7.5 \times 10^{3}$ & 100.0 \\
Taurine & $1.3 \times 10^{3}$ & 100.0 \\
Glucose & $3.6 \times 10^{3}$ & 100.0 \\
Oxalic acid & $1.8 \times 10^{2}$ & 97.3 \\
Citric acid & $3.8 \times 10^{3}$ & 100.0 \\
Tartaric acid & $3.0 \times 10^{3}$ & 100.0 \\
Ascorbic acid & $1.8 \times 10^{3}$ & 100.0 \\
Bilirubin & $5.8 \times 10^{3}$ & 100.0 \\
Uric acid & $8.4 \times 10^{2}$ & 100.0 \\
Allantoin & $2.1 \times 10^{3}$ & 100.0 \\
Creatinine & $2.3 \times 10^{3}$ & 100.0 \\
Hippuric acid & $1.8 \times 10^{3}$ & 100.0 \\
Sodium oleate & $2.0 \times 10^{2}$ & 100.0 \\
Caffeine & $3.9 \times 10^{3}$ & 100.0 \\
\hline
\end{tabular}

HSA taken, $50 \mu \mathrm{g}$; SPF, $5.0 \times 10^{-5} \mathrm{M}$; Ti(IV), $5.0 \times 10^{-5} \mathrm{M}$; surfactant, $3.0 \mathrm{~cm}^{3} / 10 \mathrm{~cm}^{3} ; \mathrm{pH}, 2.2 ;$ reference, SPF-Ti(IV) solution.

methods. ${ }^{1-5,7-9}$ The relative standard deviation is $0.17 \%$ $(n=5)$ for $50 \mu \mathrm{g}$ of HSA. There was a remarkable rise in the precision.

\section{Effects of foreign substances}

For an assessment of its usefulness in urinary protein assays, the influence of various foreign substances on the detemination of HSA was examined. Among foreign substances, the presence of iron(III) ion resulted in a slight increase in measurement. A small amount of fluoride ion and large amounts of phosphate and oxalate ions caused minor decreases in absorbance. Absorbance values were hardly affected at their usual concentrations in the sample solution. Other substances exerted practically no effect on absorbance. The results are summarized in Table 2.

\section{Correlation with the PR method}

The present method and the PR method (commercially available total protein assay kit, micro TP-test Wako, Wako Pure Chem.) were compared for human urine samples. A regression line was estimated using the least squares method. The present method correlated well with the PR method ( $r=0.956 ; y=1.217 x-8.264 ; n=30)$, as shown in Fig. 3. The value $(\bar{y}=91.85)$ determined by the present method was somewhat large in comparison with that $(\bar{x}=82.52)$ obtained by the PR method. The PR method is reported to be more sensitive to HSA than $\gamma-G^{11-14}$ Compensation for differences in sensitivity is achieved by this improved SPF-Ti(IV) method.

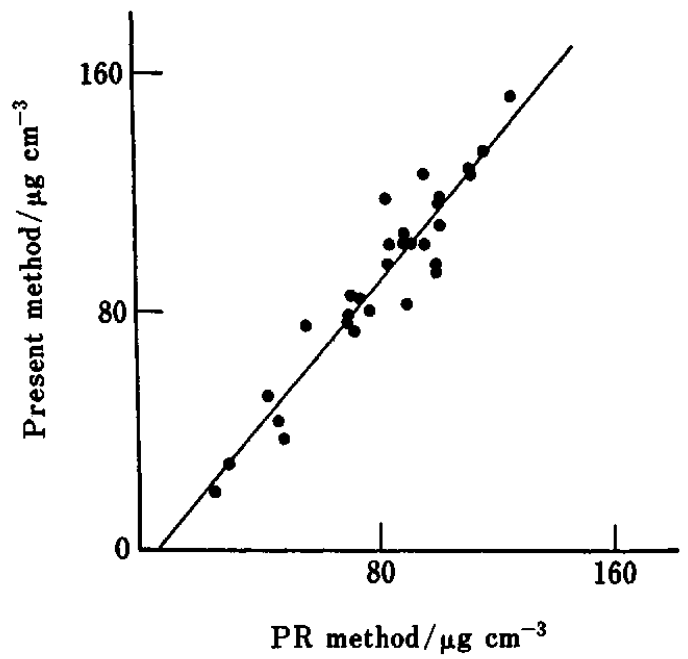

Fig. 3 Comparison of the present method and the PR method for urinary protein assay in humans.

In conclusion, the advantages of this procedure developed for proteins can be summarized as follows:

(1) This method achieved similar sensitivities to HSA and $\gamma-\mathrm{G}$.

(2) This method was more sensitive than the previous SPF-Ti(IV) method. ${ }^{6}$

(3) There was a remarkable improvement in the precision by this method.

Though the study of the response of other proteins, for example Tamm-Horsfall protein, is necessary, the improved SPF-Ti(IV) method will be avaiable for total urinary protein assays.

A part of this work was presented at the 115th Annual Meeting of the Pharmaceutical Society of Japan, Sendai, March 1995.

\section{References}

1. Y. Fujita, I. Mori and S. Kitano, Bunseki Kagaku, 32, E379 (1983).

2. Y. Fujita, I. Mori and S. Kitano, Chem. Pharm. Bull., 32, 4161 (1984).

3. Y. Fujita, I. Mori, K. Fujita, Y. Nakahashi and T. Nakanishi, Yakugaku Zasshi, 107, 640 (1987).

4. Y. Fujita, I. Mori, K. Ikuta, Y. Nakahashi, K. Kato and T. Nakanishi, Chem. Pharm. Bull., 37, 2452 (1989).

5. Y. Fujita, I. Mori, M. Toyoda, K. Kato, M. Nakamura and T. Nakanishi, Chem. Pharm. Bull., 38, 956 (1990).

6. Y. Fujita, I. Mori and M. Toyoda, Anal. Sci., 7 (supplement), 771 (1991).

7. Y. Fujita, I. Mori and M. Toyoda, Anal. Sci., 8, 313 (1992).

8. Y. Fujita, I. Mori and M. Toyoda, Anal. Sci., 8, 693 (1992).

9. Y. Fujita, I. Mori and T. Matsuo, Bunseki Kagaku, 44, 733 (1995). 
10. H. Sano, Bull. Chem. Soc. Jpn., 31, 974 (1958).

11. H. H. Nishi, J. Kestner and R. J. Elin, Clin. Chem., 31, 95 (1985).

12. M. P. Goren and J. T. L. Li, Clin. Chem., 32, 386 (1986).

13. N. Watanabe, S. Kamei, A. Ohkubo, M. Yamanaka, S. Ohsawa and K. Tokuda, Clin. Chem., 32, 1551 (1986).
14. J-L. Orsonneau, P. Douet, C. Massoubre, P. Lustenburger and S. Bernard, Clin. Chem., 35, 2233 (1989).

(Received January 16, 1997) (Accepted February 20, 1997) 